\title{
“A VIEW FROM THE BAR”
}

\author{
Michael J Beloff $Q C^{1}$ \\ THE TENTH SIR DAVID WILLIAMS LECTURE \\ (TFV)

\section{DELIVERED AT \\ LAW FACULTY: CAMBRIDGE UNIVERSITY ON $21^{\text {ST }}$ MAY 2010}

The sense of privilege that I feel in being invited to deliver this lecture is tempered by my sadness that the distinguished lawyer, in whose honour it was founded, is no longer with us.

David was a friend of, and mentor to, me for many years. We first met in the 1960s when he was a Law Fellow at Keble, Oxford - a part of his career which was mysteriously airbrushed from the Memorial Service which took place earlier this year in Great St Mary's Church. He became an academic tenant in the chambers at 4/5 Grays Inn Square of which I was then joint head. He acted, as he put it, as my "junior" when I chaired the Judicial Subcommittee of the Senior Salaries Review Body: We were clearly suspected in tandem of apparent, if not actual, bias towards the payees, since at the conclusion of our term no lawyers appointed were to replace us. He was one of my referees when I became President of the smaller - I choose the adjective with care - of the two Oxbridge Trinities. It was characteristic of David, whose modesty was preeminent among his many memorable qualities, that in asking me to be the tenth lecturer in this series, he told me only after I had accepted, that he was in all likelihood destined not to be among the audience. Alas, his prophecy was fulfilled. I miss him greatly.

My predecessors as lecturer have all been lawyers of the highest repute the last four being Chief Justices of major democracies. Indeed for me to follow in the immediate footsteps of the Chief Justice of the United States of America, albeit a stripling some years younger than I, risks giving a new meaning to the word 'bathos'. But incapable of matching these generals in

\footnotetext{
${ }^{1}$ Blackstone Chambers, the Temple, sometime President of Trinity College and Treasurer of Gray's Inn, Senior Ordinary Appeal Judge of Jersey and Guernsey, Judge of the First Tier of the Upper Tribunal.
} 
delivering ex cathedra statements from the mountain peaks of the law, I, a mere foot soldier, have decided to pitch my perspective from its plains.

I have been for more than four decades a member of the Bar of England and Wales so crossing what my researches for this lecture identify as a chronological plimsoll line. In the Bodleian Law Library I came across two memoirs entitled "Forty Years at the Bar" one by Edward Abinger, ${ }^{2}$ the other by James Balfour-Bowen ${ }^{3}$ only to find, a few shelves on, a volume entitled "72 years at the Bar" by Ernest Bowen-Rowlands ${ }^{4}$ - a quantum leap of forensic longevity, equivalent in terms of record breaking to Usain Bolt's exploits as a sprinter. Abinger's plea in mitigation for his autobiography rested on the coincidence that, as he wrote, he had "nearly attained the three score years and ten usually allotted to men" coupled with the urgings of his many friends ${ }^{5}$. I could only avail myself of half of that not altogether convincing excuse. And it is not my purpose, in mimicry of these worthies, merely to indulge in titivated court room reminiscence, nor to give an apologia pro vita mea, although my lecture will be in part a credo. At the end of that classic sixties film Alfie, the hero played by Michael Caine, turns towards the camera, and asks "What's it all about?" It is that question, as a veteran ${ }^{6}$ jobbing attorney, that I shall seek to answer.

But let me start my voyage in that now iconic decade.

I was called to the Bar by Grays Inn in November 1967. In order to qualify, aspirant barristers who did not need to be graduates, could study law in their own time, from nutshell notes, scripted by Gibson and Weldon. My practical training consisted of watching my pupil-master, to whom I was apprenticed for the next year, and learning from his trials and his errors in equal measure. For this facility I had to pay him the princely sum of $£ 50$.

In those days barristers still conventionally wore cutaway black jackets and striped trousers; and a handful continued to affect bowler hats. There were few females in the profession - in the year of my Call approximately 7\% of new barristers. Objections were still voiced, devoid of any sense of shame, to women being admitted to chambers on the basis that they would inevitably soon depart to pursue their proper and predestined role of child bearing and rearing.

\footnotetext{
2 (Hutchinson, 1930).

3 (Herbert Jenkins, 1971).

4 (Macmillan, 1924). I passed over J Law My Sixty Years in the Law (Bodley Head, 1936) - the recollections of a Judge's clerk.

5 Ibid, p 7.

${ }^{6}$ So described in the Gibraltar Chronicle when appearing in the Privy Council for the Chief Justice in Hearing on the Report of the Chief Justice of Gibralter Referrals under section 4 of the Judicial Committee Act 1833 [2009] UKPC43, the day before I was identified on the same journal as "imminent” (sic).
} 
Ethnic minority counsel were still rarer. While the Inns of Court played host to a significant proportion of overseas students from new Commonwealth and old Empire, those same students were expected to return to their own countries and exploit the title of barrister-at-law to immediate advantage, accelerating to positions such as Attorney General or even Chief Justice with a velocity which their English equivalents could only emulate in their dreams.

Chambers were generally small - my own set, 2 Hare Court, had, when I arrived, 12 members and no QCs. Chambers' names were then their addresses too. Membership was for life. Departure from the set to which one had been admitted as a tenant, indeed as a pupil, on the solitary say-so of the Head of Chambers, himself selected on the principle of Buggin's turn, was as rare, and as disagreeable, as divorce.

Chambers' administration rested exclusively on the clerks, who arranged one's diary, negotiated one's fees, and took $10 \%$ of them - the so-called shilling in the guinea.

Control of the profession still rested substantially with the Inns: the Bar Council being more a representative than a regulatory body and its Chairman, in Bagehotian terms, more dignified than efficient.

Solicitors were a segregated, separate and unequal branch of the legal profession. The relationship between barrister and solicitor was a vertical, not a horizontal one, even though solicitors were the single source of barristers' instructions. On that basis solicitors came to seek advice only in the barristers' chambers. It was a breach of the bar's professional etiquette to fraternise with them; or otherwise to advertise a barristers' own expertise (such as it was) however discreetly. The all but omnipotent clerks acted as the barristers' agent to the outside world, and could make, but also break, careers. ${ }^{7}$

Solicitors enjoyed no rights of audience in the higher courts of law, where silks still appeared with juniors who were paid $2 / 3^{\text {rds }}$ of their leader's fee. Judicial appointments were made entirely from the ranks of Bar. The Lord Chancellor by means of the usual - but archaic - processes of consultation himself determined who should become a Queen's Counsel or a Judge. It was clear that some who aspired to such status had a black mark against them; but who had put it there was obscure; and there was no formal means by which it could be exposed, still less eradicated. It was assumed that most barristers did aspire to the High Court Bench. If invited to accept such an appointment, a QC was expected to accept it; and one Judge, Harry Fisher, who swiftly abandoned the office, first in favour of City and then of University life, after brief exposure - I parody - to the monotony of personal injury litigation in

${ }^{7}$ See the obituary of Ron Burley, clerk to, amongst others, Lord Alexander, Lord Phillips, Sir Sidney Kentridge QC, and Jonathan Sumption QC in The Times $8^{\text {th }}$ April 2010. 
Sunderland, punctuated by the occasional affray in Darlington, was regarded as having done that which a gentleman should not do.

In Court the tradition of oral advocacy and oral evidence was unchecked: precedents relied on would not infrequently be recited in full. Judges conventionally declined to read any papers before coming into court in case it prejudiced their otherwise open minds. They acted as referees, determining who won or lost, penalising breach of rules, but otherwise uninvolved. Cases would be frequently adjourned for "Counsel's Convenience" or sometimes because the Judge had "a public duty to perform" - occasionally a euphemistic synonym for an invitation to a Royal garden party. Barristers uniquely among the profession were immune from suits for negligence ${ }^{8}$, although also they could not sue for their fees. The only established form of dispute resolution, alternative to litigation, after the demise long since of the duel, was arbitration.

The technology to support such litigation was immature. Typewriters were at best electric, not electronic: the fax machine had but recently arrived on the scene; the word processor was unheard of. Blackberries were still fruit. Copying files was a laborious process. Conferences took place face to face. Research was done in libraries. Judges recorded evidence and argument in manuscript.

Under the legal aid system inaugurated in $1949,{ }^{9}$ in broad terms anyone who satisfied a means and merits tests could walk through the door of any solicitor who was entitled, regardless of expertise, to take with Counsel's assistance, a case through from start to finish at public expense.

England was truly an off-shore island in the legal world. Although QCs could still travel to exotic regions of the old Empire - Singapore, Malaysia, Hong Kong, the Caribbean islands, newly independent African states - to appear in full fig and with white wig in courtrooms cooled only by revolving fans, the domestic common law was uninfluenced by the law of the Common Market, or by the European Convention on Human Rights. The writings of academics were only cited in court after their authors were dead, but not, by venerable tradition, before.

Fast forward the clock to 2010, four and a half decades later. How different is the picture!

Barristers are still called to the Bar by the Inns of Court - institutions of medieval origin but with considerable staying power, but the Bar is now a wholly graduate profession. Pupillage is still a necessary part of the aspirant barrister's education; but it is preceded even for those, who with law degrees, are spared the monotony of the Graduate Diploma in Law by a year's specific

\footnotetext{
${ }^{8}$ Rondel v Worsley [1969] 1 AC 191.

${ }^{9}$ See for its development Walker and Walker The English Legal System (Oxford: OUP, $10^{\text {th }}$ edn, 2008) pp 403-404.
} 
training by the Bar Professional Training Course ${ }^{10}$ in such matters as advocacy, negotiation, client relations and other matters which previously the fledging barrister had been expected to acquire by a mysterious osmotic process.

Pupils no longer pay for the privilege of pupillage, now itself a structured training programme; on the contrary the major sets of chambers fall over themselves to offer substantial scholarships of up to $£ 50,000$ per annum to attract the best and brightest of their generation. OLPAS, the Mark 2 model of PACH - the pupil's application clearing house, itself based on UCAS, restricts the window for applications to a specified time of the year - in common with professional football transfers - to prevent unseemly competition.

The barristers' formal attire of yesteryear gathers mothballs in the attic. Dark suits are still obligatory - although the concept of darkness appears somewhat flexible. Women, who now constitute $58 \%$ of those admitted to the profession, usually wear the trousers.

Minority ethnic counsel are on the rise, constituting almost 24\% of pupils in 2007.

Chambers are larger. In Birmingham two sets have more than 100 tenants. My old set now numbers 75, of whom almost half are QCs. It has been rechristened Blackstone in the modern style, where no significant figure in English legal history from Bracton and Erskine, to Denning and Wilberforce has not been pillaged to add borrowed lustre to a chamber's name - not to speak of Matrix, professional home of Cherie Booth, which has looked to Hollywood rather than history or the House of Lords for inspiration in its title.

Tenants, and pupils, are chosen by a rigorous process conforming to modern best practice, informed by anti-discrimination legislation and the Human Rights Act. And not only is it now conventional for upwardly mobile barristers to move to different sets, but transfers are even solicited, again just as they are between football clubs.

The clerks, a durable race, have been supplemented by Practice Managers or even by Chief Executives - all now salaried. The clerk's 10\% has gone with the wind, once it was appreciated that its survival would guarantee the recipient an income far in excess of that enjoyed by the highest earning barrister.

The Bar itself has been affected by waves of legislative regulation: the Courts and Legal Services Act 1990, the Access to Justice Act 1999, the Legal Services Act 2007. In order to react to but also to anticipate further control, the Bar Council has become an executive engine, spawning committees, position papers and guidelines on every subject from international relations to maternity leave; the Chairmanship is a full time post.

${ }^{10}$ Formerly the Bar Vocational Course. 
The balance of power between the professions has shifted. Barristers will dispense advice in solicitor's offices. Solicitors are no longer prohibited guests; but encouraged to attend chambers' parties, where they are wooed with champagne and canapés - some would say excessively. Movement within the Bar is paralleled by movement from one profession to another. Between the Bar and solicitors is no longer a Rubicon but a rivulet.

There is a wealth of legal directories in which lawyers' specialities can be recorded. It is nonetheless irritating to be flattered by some publisher as a leading expert in a particular field, but then invited to pay several hundred pounds so that this remarkable piece of intelligence can be broadcast to the wider world. These weighty volumes proliferate with their own ranking lists, treated by barristers with reverence or contempt depending on how they are personally assessed - in the same way as politicians variously treat opinion polls. There are the lawyers' equivalent of the Oscar and BAFTA ceremonies held in the ballrooms of leading London hotels in which titles such as "Construction and Technology Junior of the Year" are handed out by celebrity compères.

Solicitors, subject only to fulfilment of certain criteria in terms of experience and training, have rights of audience in the highest courts, where QCs now often appear without the buttress of a Junior. As quid pro quo the Bar has promoted direct access, cutting out the solicitor middleman. This has not, despite dire predictions, brought a halt to the expansion of the independent Bar. When I was called there were 2,300 barristers in independent practice: now there are over 12,000. In the law's house there are many mansions. There will always be scope for the buccaneer as well as the backroom boy.

Solicitors can aspire too to the highest judicial posts: QCs as well as Judges are chosen by Commissions with a strong lay component. ${ }^{11}$

But the Bench itself is no longer the inevitable culmination of a successful career at the Bar. The charms of college or boardroom, a preference for advocacy over adjudication and the growing gulf between the income of a fashionable silk and even the Lord Chief Justice has ensured that by no means all who could be on the High Court bench are, or, increasingly, will be.

Modern technology has transformed the operation of the law. Video conferencing has become common. Courts can accommodate simultaneous display of evidence on screen. Submissions are handed up and judgments handed down on disk. Research is increasingly done through the electronic

\footnotetext{
${ }^{11}$ The Lord Chancellor's residual and qualified right of veto over senior judges can delay but not determine the outcome, as is shown by the recent appointment of an outspoken critic of the government's policies on children to the Presidency of the Family Division.
} 
database and the world-wide-web. Professor Richard Susskind has termed the lawyers of the future "legal information engineers".

In Court, influenced by civilian and transatlantic example, written now accompanies oral advocacy. Skeleton arguments and witness statements have to be provided. Judges are expected to read them in advance, and some indeed do. They have become case managers controlling the timing and pace of litigation, conscious of the need to meet targets and to cut costs. Barristers can be sued for negligence, ${ }^{12}$ and even exposed to wasted costs orders. ${ }^{13}$ They are obliged to carry insurance but can enter into contracts to provide legal services to their professional clients. Adjudication has been part privatised, with mediation and other forms of $\mathrm{ADR}^{14}$ supplementing more conventional arbitration.

There is a Community Legal Service and a Criminal Defence Service - a system of state defenders - to complement the Crown Prosecution Service. Old style conventional legal aid for civil work has swept away - it no longer exists for personal injury claims or most damages actions, and the Legal Services Commission enters into franchised contracts with vetted practitioners to provide services. Conditional fees are now allowed to support privately funded litigation.

It is closing time in the Gardens of the East. Malaysia has ceased to be an area where English silks can appear; Singapore almost so, and, even in Hong Kong the Bar Council operates a justifiable protectionist policy. Strasbourg and Luxembourg have provided new fora to replace the old.

In civilian terms doctrine as well as jurisprudence can be relied on in litigation: and living academics can collect the number of their citations in judgments as well as in the footnotes in prestigious journals. Comparative law has infiltrated forensic argument. As Tom Bingham presciently noted "There is a world out there". ${ }^{15}$

But has the transformation of the context transformed the content? Are the values and the virtues of the Bar what they were? Can they, and should they, survive this tsunami of reform, ${ }^{16}$ whether imposed from without or generated from within?

Tom Bingham, amplifying his much quoted Williams Lecture on the rule of law into a slim volume, wrote in his chapter on a Fair Trial:

\footnotetext{
${ }^{12}$ Arthur Hall v Simmons [2002] 1 AC 615: See too May \& Peltman [2005] 1 WLR 581.

${ }^{13}$ CLSA Section 5: substituting a new Section 51 in the Supreme Court Act 1981 and Ridehalgh v Horsefield [1994] Ch 205 ep p236, Medcalfe v Mardell [2003] 1 AC 120.

${ }^{14} \mathrm{H}$ Brown and A Marriott ADR Principles (Sweet and Maxwell, 1999).

15 The FA Mann Lecture (1992) 41 ICLQ at 513-529.

${ }^{16}$ See M Burrage Revolution and the Making of the Contemporary Legal Profession (OUP, 2006) Ch 14 XVI and XVII.
} 
"scarcely less important than an independent judiciary is an independent legal profession, fearless in its representation of those who cannot represent themselves, however unpopular or distasteful their case may be."

In that single sentence are identified three elements crucial to the Bar's ethos $^{18}$ : availability, fearlessness and independence - but the greatest of these is independence.

It is the availability as much as the quality of representation which is the guarantee provided by the Bar. Under the so-called cab-rank rule any barrister not otherwise engaged or conflicted out and competent in the relevant area of law must appear for any client willing and able to pay an appropriate fee, even if he disapproves of the clients' character or cause. ${ }^{19}$ It was said to be, in one analysis of legal ethics "to barristers what the Hippocratic oath is to doctors".

In Arthur Hall $v$ Simmons ${ }^{20}$ the Law Lords variously described it "a valuable professional rule" ${ }^{21}$ or "ethic", a "long and honourable tradition", 23 as "a fundamental and essential part of a liberal legal system" ${ }^{24}$ and

“a public duty which advocates perform without regard to such private considerations such as general gain or personal inconvenience. ${ }^{25}$.

In the same case various rationales were supplied. The rule ensures that no-one is left without representation even the most

“unpopular and anti-social.,"26

"It protects barristers against being criticised for giving their services to a client with a bad reputation.,27

${ }_{17}$ (Penguin, 2010) pp 92-93.

18 As to which see generally: A Boon and J Levon The Ethics and Conduct of Lawyers in England and Wales (Hart, 1999) Ch 14 “Advocacy Services”.

${ }^{19}$ See now The Courts and Legal Services Act 1990 (“CLSA”) s 17(3)(a).

${ }^{20}$ [2002] 1 AC 612. See further Adoyomi v Radford [2008] QB 793, holding that its effect was not prospective only.

${ }^{21}$ Lord Steyn at 678.

${ }^{22}$ Lord Hoffman at 686.

${ }^{23}$ Lord Hope at 714.

${ }^{24}$ Lord Hobhouse of Woodborough at 739.

${ }^{25}$ Lord Hope at 714.

${ }^{26}$ Lord Hobhouse of Woodborough at 739.

${ }^{27}$ Lord Hoffman at 686. 
"It negates the identification of the advocate with the cause of his client and therefore assists to provide him with protection against governmental or popular victimisation., ${ }^{, 28}$

Some have elsewhere pitched its justification high. Erskine defended his own defence of Thomas Paine, author of the Rights of Man, with the words:

"From the moment that any advocate can be permitted to say that he will or will not stand between the Crown and the subject from that moment the liberties of England are at an end." 29

Some have pitched it low. Geoffrey Robertson QC wrote:

"it reduces the amount of excrement through the letter box., "30

Yet the virtues of the cab rank rule are not always recognised outside the profession.

The abolitionist Granville Sharp, the prime mover in Somerset's case $e^{31}$ when Lord Mansfield famously determined that slavery was unlawful in England, criticised Dunning, Counsel for slave owner, who had represented a slave in an earlier case for his forensic volte face, recording his disapproval of:

"an abominable and insufferable practice in lawyers, to undertake cases diametrically opposed to their own declared opinions of law and common justice."32

And when I appeared within the Committee of Privileges in a vain effort to postpone the ejection of the hereditary peers from the House of Lords, ${ }^{33}$ Margaret Jay, then Leader of the House, came up to me in the Moses Room shortly before the hearing and expressed her surprise at my appearance, as she phrased it, "on that side". But when some years later in an article in The Spectator I suggested that retired members of the University who lived in Oxford had no more obvious right to vote on the University affairs than hereditary peers to participate in the deliberations of the Upper House, Lord Trefgarne, one of my sometime clients, wrote a letter complaining that my

${ }^{28}$ Lord Hobhouse of Woodborough at 739-40.

${ }^{29} 179222$ State Trials 358 at 412.

${ }^{30}$ G Robertson The Justice Game (Chatto \& Windus, 1998) pp 377-9.

31177220 State TV1.

${ }^{32}$ E Heward Lord Mansfield (Barry Rose, 1998) p 145.

${ }^{33}$ Lord Mayhew of Twisden's Petition [2002] 1 AC 109. 
views seemed inconsistent with my representation of the hereditary interests in the earlier litigation.

Others have suggested that the rule is more mantra, than mandate. Lord Steyn in Arthur Hall said:

"Its impact on the administration of justice is not great. In real life a barrister has a clerk whose enthusiasm for unwanted brief may not be great, and he is free to raise the fee within limits." 34

Yet the menace, if any, comes less from avarice than from ideology. In setting up chambers, in Lambeth as a barristers' co-operative where profit was not the prime mover, Lord Gifford, hereditary peer and soi-disant Passionate Advocate said:

"we let it be known that we would not want to prosecute cases for police, nor would we act for landlords against tenants or for employers against employees."35

Threatened with disciplinary proceedings by the Bar Council, he ingeniously defended that stance on the basis that his Chambers had indicated a preference, not imposed a prohibition. But even in sets which house the alternative Bar or those of avowedly left of centre persuasion, there is no reason to believe or evidence to support that their members could, or indeed would purge from themselves what the current Chairman has called "the DNA of the Bar". ${ }^{36}$

As a barrister cannot disdain neither can he prejudge his clients' case Dr Johnson said:

"A lawyer has no business with the justice or injustice of the cause which he undertakes, unless his client asks his opinion, and then he is bound to give it honestly. The justice or injustice of the cause is to be decided by the judge."37

${ }^{34}$ Lord Hobhouse at 739 "Regrettably not all barristers observe it even though such failure involves a breach of their professional code".

35 A Gifford The Passionate Advocate (Wildy, Simmons and Hill, 2007) p 19. (Hereafter: “Gifford”).

${ }^{36}$ Bar Council Chairman Inaugural Speech: Nicholas Green QC 7th December 2009 "No one has been reported in recent years for any alleged infringement of the cabrank rule, and particularly in the criminal sphere it is a rule which is zealously observed.” Thornton cit sup.

${ }^{37}$ Dr Johnson 15 August 1773, in J Boswell The Journey of a Tour to the Hebrides with Samuel Johnson, LLD, 1785. 
So does the barrister then, in accepting a brief, become monocular or may he have a broader vision?

Henry Brougham to justify his controversial defence of Queen Caroline proclaimed:

"An advocate, by the sacred duty which he owes his client, knows in the discharge of that office but one person in the client and none other, ...he must go on reckless of the consequences, even if his fate it should unhappily be, to involve his country in confusion for his clients protection., ,38

By contrast Lord MacMillan, a Law Lord, commented extracurially:

"In the discharge of his office the advocate has a duty to his client, a duty to his opponent, a duty to the Court, a duty to the State, and a duty to himself. To maintain a perfect poise amidst these various and sometimes conflicting claims is no easy feat." ${ }^{\text {,39 }}$

Amongst that quintet of perceived obligations, only a pair may command general agreement - the duty to the Court and the duty to the client, the former wrongly omitted from Brougham's catalogue of one. As is recorded in the Gospel according to St. Matthew no man may serve two masters; ${ }^{40}$ but a barrister must. He owes, as Lord Hoffmann put it "a divided loyalty", ${ }^{41}$ for the duty to the client is subordinate to advocate's principal duty. Lord Denning gave a classic enunciation of the duty's pith and purpose. He said of the barrister:

"He has a duty to the court which is paramount. It is a mistake to suppose that he is the mouthpiece of his client to say what he wants: or his tool to do what he directs. He is none of these things. He owes allegiance to a higher cause. It is the cause of truth and justice." ${ }^{42}$

\footnotetext{
${ }^{38}$ Quoted in D Nicholson and J Webb Professional Legal Ethics (OUP, 2000 ) p 162.

${ }^{39} \mathrm{H}$ MacMillan The Ethics of Advocacy in Law and Other Things (Cambridge 1938) p 185.

${ }^{40}$ Matthew 6.24.

${ }^{41}$ Arthur Hall 628.

${ }^{42}$ Rondel $v$ Worsley [1967] 1 QB 443 at 502.
} 
The practical effects of this duty now enshrined in statute ${ }^{43}$ are many, ${ }^{44}$ and illuminated by a wealth of judicial dicta.

An advocate may not deceive or knowingly mislead the court ${ }^{45}$ nor allow the judge to take what he knows to be a bad point in his client's favour. ${ }^{46} \mathrm{He}$ must bring to the attention of the court all relevant decisions and legislative provisions of which he is aware, even those that are adverse to his argument. ${ }^{47}$

He must conduct the proceedings economically and "not waste time on irrelevancies even if the client thinks they are important", ${ }^{48}$ and notwithstanding, as the Chief Justice of Australia Anthony Mason graphically put it, that

"the client may wish to chase every rabbit down every burrow". ${ }^{49}$

Still less may he "take false points however much his client may insist he should do so". ${ }^{50}$ He must help the court to further the overriding objective of the Civil Procedure Rules. ${ }^{51}$ He must not set his name to a plea which "he does not consider to be properly arguable". ${ }^{52}$

43 See sections 27(2A) and 28(2A) of the Courts and Legal Services Act 1990 as inserted by section 42 of the Access to Justice Act 1999.

Section 27(2A) of the Courts and Legal Services Act 1990 (CLSA 1990) provides:

'Every person who exercises before any court a right of audience granted by an authorised body has -

a duty to the court to act with independence in the interests of justice; and

a duty to comply with rules of conduct of the body relating to the right and approved for the purposes of this section

and those duties shall override any obligation which the person may have (otherwise than under the criminal law) if it is inconsistent with them.' See too Basic Principles on the Role of Lawyers adopted in 1990 by the Eighth United Nations Congress on the Prevention of Crime and Treatment of Offenders Principle 14. Lawyers should at all times at "freely and diligently in accordance with the law and recognised standard and ethics of the legal profession". They are also of course found dispersed throughout the Bar Council's Code of Conduct, the first edition of which dates only to 1980.

44 See generally DA “Lawyers’ Duties to the Court” (1998) 114 LQR 63.

${ }^{45}$ Frape v Emreco International Limited [2002] EuLR 10 per Lord McEwan [21].

${ }^{46}$ Lord Hoffmann: Arthur Hall: 686 Meek v Fleming [1961] 2 QB 366.

${ }^{47}$ Lord Hoffmann: Arthur Hall: 686.

${ }^{48}$ Arthur Hall: Lord Hoffmann at 686.

${ }^{49}$ Gianarelli $v$ Wraith (1988) 165 CLR 543 at 556.

${ }^{50}$ Arthur Hall: Lord Hope at 715.

${ }^{51}$ per Arden LJ in Geveran Trading Co. Ltd v Skjevesland [2003] 1 WLR 912 [37]

${ }^{52} R$ v Horsham District Council ex parte Wenman [1995] 1 WLR 680 per Brooke J at p 698. 
He must not unjustly make a charge of fraud, without evidence to support it. ${ }^{53}$ He must see that his client disclose relevant documents, even those that may be fatal to his case. ${ }^{54}$

These principles apply to barristers in criminal as well as in civil proceedings. Prosecuting counsel play an important public role in promotion of an open and fair criminal justice system, ${ }^{55}$ so the Bar Council prescribes:

"Prosecuting counsel should not attempt to obtain a conviction by all means at his command". ${ }^{56}$

- although Mervyn Griffith-Jones QC qualified this by warning Middle Temple Students in 1973

“don’t act as second defending counsel as some young men seem to think they should do in order to be fair". ${ }^{57}$

When, twelve years earlier, prosecuting Penguin Books, the publishers of Lady Chatterley's Lover, as Crown Counsel he lost the jury's sympathy in his opening speech by asking them whether it was a book that a jury man would like his wife or servants - I stress the plural - to read, ${ }^{58}$ he was presumably not anticipating his own later advice.

While the defence lawyer's role in criminal proceedings is essentially partisan, ${ }^{59}$ he is still required to place the interests of justice first. ${ }^{60}$

If his client confesses his guilt prior to trial, he is limited to testing the strength of the prosecution case. He must not 'set up an affirmative case

${ }^{53}$ Brown v Bennett (No 2) [2002] 1 WLR 713 [104] per Neuberger J.

${ }^{54}$ Rondel $v$ Worsley 1967 QB at 502 per Lord Denning MR). In Vernon v Bosley (No

2) [1999] QB 18, a disclosure case Thorpe LJ said at p 64 "In general terms the balance between the advocate's duty to the client and the advocate's duty to the court must reflect evolutionary change within the civil justice system. If evolutionary shifts are necessary to match civil justice reforms they should in my judgment be towards strengthening the duty to the court".

${ }^{55}$ See the Farquharson Guidelines on the Role and Responsibilities of the Prosecution Advocate (published by the Crown Prosecution Service).

56 The Bar Council's Written Standards for the Conduct of Professional Work para 10.1 .

57 Basic Elements of Advocacy: Mervyn Griffith-Jones MC Reading 1973, Middle Temple Hall p 10.

${ }^{58}$ C Rolph The Trial of Lady Chatterley: Regina v Penguin Books Limited (Penguin, 1990).

${ }^{59} R$ v Puddick (1865) 4 F \& F 497 at 499 per Crompton J. A Ashworth The Criminal Process (Oxford, $2^{\text {nd }}$ edn, 1998) p 69.

${ }^{60}$ See generally, $R$ v McFadden (1975) 62 Cr App R 187. 
inconsistent with that confession nor call evidence in support of an alibi or otherwise which he knows to be untrue. ${ }^{61}$

Subject to that proviso, as again the Bar Council prescribes:

"It is the duty of counsel when defending an accused on a criminal charge to present to the court fearlessly and without regard to his personal interests." ${ }^{\prime 62}$

Counsel may be partially consoled, by the obiter dictum of Lord Justice James in $R v$ McFadden:

"Forensic techniques may vary from time to time but it is still possible to point to success at the Bar based upon a reputation for courage in standing up to the judge when occasion demands."

It is, however, worth pausing for a moment to reflect upon the significance of this unusual constraint, and to imagine its impact if were transposed, mutatis mutandis, as we were once permitted, but no longer, to say in submissions to the Court, to other arenas. We are a mere fortnight away from a general election in which politicians appealed to the verdict of the people, who gave what might reasonably be described as a reserved judgment, indeed a split decision. During the campaign - and I make no partisan pointthere was a wealth of examples, in the language of old fashioned pleading too numerous to specify, of suppressio veri - economy with the truth - if not of suggestio falsi. Imagine for a moment how the democratic process would be transformed and improved if politicians were under a duty not to deform statistics, or to make full and frank disclosure, of material, say, relating to the national debt. Imagine for a moment if cricketers walked, footballers refrained from diving, rugby players from committing that contradiction in terms the professional foul, or team managers in any game from berating match officials, how that too would purify the culture of sport. That barristers operate in this unusual way is not a testament, of course, to their inherent morality; they are cut from the same crooked timber of humanity as all of us. But as with the cab-rank rule, the duty to the court, the second pillar of the Bar's wisdom, is something rare and precious, to be preserved and protected.

\footnotetext{
${ }^{61}$ Written Standards for the Conduct of Professional Work paragraphs 12.1 and 12.4, though see the provocatively entitled A McBride Defending The Guilty, Truth and Lies in the Criminal Courtroom (Viking, 2010).

${ }^{62}$ Ditto.

63 (1975) 62 Crim App Rep at 187.
} 
In my view the duty to the Court, deeply embedded in the English common law tradition, no more acts as an undesirable restraint on the barrister's freedom of action than do the Queensberry rules on professional pugilists. Indeed, as the same Chief Justice of Australia said, it fortifies him in the exercise of an independent discretion or judgment in the conduct and management of a case. ${ }^{64}$

How far then should the barrister himself fortify the structures of independence? Should a barrister be a cause lawyer or a case lawyer? Autobiographies with titles such as Memoirs of a Radical Advocate ${ }^{65}$ or even the Passionate Advocate, ${ }^{66}$ (more intriguing perhaps than even "72 years at the Bar"), are accounts of the careers of advocates who, without violating the cab-rank rule, wear on their sleeve not only their hearts, but their minds. Why do I prefer an alternative style in which the barrister's views are as private as his vote, even accepting the price to be paid in erosion of civic commitment and even of moral sensibility?

There are two reasons: one is actuality, one is appearance.

The function of the advocate to give advice and then to conduct a case with detachment, his only passion being for success on behalf of his client. Ideological, or emotional involvement in an outcome seems to me to risk infection of analysis and presentation. I am very conscious that when I am on the side of the case I prefer, I have to guard against an excess of the adrenalin - not an exogenous prohibited substance - essential to the most effective advocacy. In 1976 I appeared in an unsuccessful effort to preserve St Marylebone Grammar school, the last of its kind in London, Lord Denning in one of his most elegiac passages was able to indicate how he would have wished to decide the case. "Many will grieve" he said "when that which was great is passed away. But so it must be". ${ }^{67}$ I grieved too, but necessarily in silence.

More recently I fear that my dislike of the Strasbourg inspired rule that the United Kingdom cannot deport individuals, proven to be a threat to its own national security, to their country of origin because of concerns about risk of the treatment they would there receive may, despite my best endeavours, have percolated into my submissions before House of Lords as a sub-text if not in the text itself. Lord Hope felt constrained to address full frontally the argument:

\footnotetext{
${ }^{64}$ Gianelli v Wright cit sup.

${ }^{65}$ By Michael Mansfield (Bloomsbury, 2009).

${ }^{66}$ Lord Gifford cit sup.

${ }^{67}$ Smith v ILEA [1978] 1 All ER 411 at p 418.
} 
"surely the sooner they are got rid of the better. On their own heads be it if their extremist views expose them to the risk of ill-treatment when they got home". 68

and administered what Touchstone called the "reproof valiant" ${ }^{69}$

"That, however, is not the way the rule of law works. The lesson of history is that, by depriving people of its protection, because of their beliefs and behaviour, however obnoxious, leads to the disintegration of society."70

Clients, be they prisoners, parents or public authorities, may welcome the barrister's sympathy as well as his skill, but they are, best served if they enjoy, without any sacrifice of courtesy on the barrister's part, only the latter. The case he advances is after all his client's not his own: that is why the advocate formally abstains from any expression of belief, and deploys the neutral concept of submission. ${ }^{71}$ But how he advances it must be the product of his own best dispassionate judgement. Alastair Campbell in his diaries records of Jonathan Sumption QC, briefed in the Hutton Enquiry:

"It was absolutely clear that he was not taking something out "(Sc: of the diaries) just because the Prime Minister would do,"72

and concluded:

"What I admired about Sumption most was that he didn't seem to care what the press or public were thinking about this. He was totally focussed on the judge". ${ }^{73}$

In circumstances of far less gravity I once had myself to tell my instructing solicitor that my client could promote his case with Max Clifford or with Michael Beloff but not with both. After, in Wednesbury terms, taking all material considerations into account, the barrister must, as Frank Sinatra would have recommended, do it his way.

\footnotetext{
${ }^{68} R B$ (Algeria) v Secretary of State for the Home Department [2009] 2 WLR 512.

${ }^{69}$ As You Like It: Act V Scene IV adopted by Lord Denning in Ex p Hook [1976] 1 WLR 1052 at 1053.

${ }^{70}$ At [209-210].

${ }^{71}$ Thornton cit sup 88.

${ }^{72}$ A Campbell The Blair Years (Hutchinson, 2007) p 746.

73754.
} 
It is, of course, difficult for emotions to become engaged in a question of construction of an arcane provision of the Hague Visby rules, or even of the obscure outer boundaries of the volatile Law of negligence. And although those who practice in the fields of criminal may from time to time develop a strong belief in a client's innocence as those who practice in the field of family law may empathise with a client in custody disputes, the issues in those cases do not easily fit into some ideological template.

It is the development of public law and its supplanting of private law as the most important element in appellate adjudication, and the concurrent migration of political issues from the legislature to the courts which expose the advocate more readily to the temptations of partisanship and more importantly to the perception of it.

In his foreword to a leading commentary on human rights practice Lord Phillips, previous holder of the triple crown of Master of the Rolls, Lord Chief Justice and Senior Law Lord, and who has now - to mix the sporting metaphor - achieved the grand slam by becoming first President of the Supreme Court - reminisced:

“...when I practised at the Bar, the staple diet of the House of Lords consisted of civil law and tax appeals... Judicial Review was in its infancy.... How things have changed. Baroness Hale and we, her colleagues, devote the majority of our energies to public law. The Human Rights Act 1998 bears significant responsibility for this change". ${ }^{74}$

In this new environment I am particularly uncomfortable with the too ready association of the barrister with his clients' case.

In the highly sensitive and increasingly complex field of immigration law in which, in my far off days as a junior, I used regularly to practice, I noted the significant attachment of clients to lawyers of their own ethnic background, not always to the advantage of their claim, ${ }^{75}$ sometimes because their chosen champion had inadequate command of the language in which the Court had to be addressed. ${ }^{76}$ I am uncomfortable too with the converse

\footnotetext{
${ }^{74}$ Lester A, Pannick D \& Herberg J Human Rights Law and Practice (LexisNexis, $3^{\text {rd }}$ edn, 2009).

${ }^{75}$ The Report of the Lord Chancellor's Advising Committee on Legal Education and Conduct (ACLEC) 1996 said in the UK immigration field barristers in order to delay deportation of a client may certify cases as appropriate for legal aid when they are clearly not.

${ }^{76}$ The language problem has, it appears, not entirely evaporated. "I was called to the Bar in 2006 and, as a British woman of Indian descent, I can hardly be accused of racism. So I perhaps feel freer to speak than some of my colleagues. But we all see
} 
position when women advocates are instructed to defend men on trial for rape - not on account of their forensic abilities but on the crude calculation that juries will be beguiled into thinking that no woman would defend someone who had committed an act of violence against members of their own sex.

I do not believe that barristers of known left wing sympathies are necessarily based placed to defend striking Trade Unionists or those of publicised Europhobic tendencies to represent UKIP. A barrister who can appear at different times for the BNP and the Socialist Workers League, is not the forensic equivalent of the Vicar of Bray, but an adherent to the true professional faith. It is dangerous to adopt a mindset that virtue can only repose on the claimants' side (or vice-versa). For it is not only the advocates for claimants but those for respondents too who are responsible for assisting in the construction or clarification of the law. Barristers, after all, do not make law, they supply from either side of the Court, the materials from which the judges can fulfil their own distinctive role.

In an essay entitled "Early Days"77 Lord Justice Sedley reminisces about his triumphs and disasters as a novice barrister, present at the creation of modern judicial review. It is an exhilarating and entertaining account of his role in seminal cases involving gypsies, low income tenants, immigrants and prisoners. In some of those I was myself involved; in the self-same case about control units, the product of a philosophy which was tough on crime, if not necessarily on its cause, being led by Stephen at first instance, and leading him in the Court of Appeal, the result of an idiosyncratic silk selection by the then Lord Chancellor, Lord Hailsham. ${ }^{78}$ But it never occurred to me that I was, or could be thought to be, bent on advancing some radical political agenda. I was simply doing my daily job. Lesser advocates than Stephen can, if they always appear on the same side of the argument, cause confusion in the minds of those who try the case between the client and his advocate to the detriment of the former. It is surely axiomatic that a barrister's arguments, whether mediated through advice or advocacy, will be given greater weight and respect if he is recognised by any test to be truly independent.

The recent case of McFarlane $v$ Relate Avon Limited ${ }^{79}$ provides a much publicised example of what I have in mind. A psycho-sexual therapist failed

the same thing: the race card being played in recruitment to legal forms and to the Crown Prosecution Service. In pubs near chambers you often hear tales of friends finding themselves up against lawyers who can barely speak English and are unable to grasp complex points of law”. S Patel, The Race Card upsets the Scales of Justice , The Sunday Times, $28^{\text {th }}$ February 2010.

${ }^{77}$ In D Dyzenhaus A Simple Common Lawyer: Essays in Honour of Michael Taggart (Hart, 2009).

${ }^{78}$ William v Home Office No2 [1981] 1 All ER 1211, 1982 All ER 564.

${ }^{79}$ Case NoA2/2009/2733. 
in his claim for religious discrimination against his employers who had refused to exempt him from providing his services to same-sex couples. He was supported by Lord Carey, the former Archbishop of Canterbury, who in a witness statement invited the Lord Chief Justice to establish a Panel of Judges designated to hear cases involving religious rights. The Appellants' advocate has a unique expertise in such cases, but as his website and record shows, is a legal crusader for evangelical religious values. ${ }^{80}$ A Counsel not only more detached but seen to be more detached from the principle contended for, of allowing religious belief to qualify from the rigidities of anti-discrimination law, might have adopted a more nuanced approach, which eschewed the gratuitous and doomed plea for a specialist non-secular court, trenchantly dismissed by Lord Justice Laws as "deeply inimical to the public interest". Those who cannot appreciate that there may be two sides to a question are not best placed to argue in favour of one.

Criminal law is not immune to this problem. Members of the Crown Prosecution Service, originally created so as to separate the functions of police and prosecutor have started to colonise frontline advocacy, with the consequent risk that as employees of a public authority they will become "prosecution minded and seen to be so". 81

The era is long since gone when it was possible to combine at one and the same time a full time practice at the Bar with an active political career. But F.E. Smith, a paradigm example of someone, who, a century ago, was able to do both, understood well the matters at stake.

When criticised by his fellow conservatives for representing the liberal Herbert Samuel in the Marconi trial he wrote to The Times:

"Political issues constantly present themselves for decision in the Law Courts. In the overwhelming majority of cases juries have done their duty indifferently between the parties, treating their own views upon politics as immaterial. How long do you think this stage of things will endure if every conservative case is to be presented by Conservative advocates and resisted by Liberal advocates.",22

\footnotetext{
${ }^{80}$ See Diamond v Mansfield \& Ors [2006] EWHC 3290 (QB) [paras 49 and 87] See too the Minutes of the AGM of the Bar Council of $16^{\text {th }}$ June 2007.

81 Inaugural speech of Nicholas Green QC, Chairman of the Bar Council 7th December 2009. There is, and has been, a long and honourable tradition of Crown Counsel at Courts such as the Old Bailey, but these were aware chosen from the independent Bar, and at the conclusion of their tenure often promptly moved into the more lucrative areas of high profile defence work.

${ }^{82}$ Issue 17 th June 1913.
} 
The Law Officers face peculiar challenges. The then Attorney General was reported to the Bar Council for investigation that his advice to the Government on the legality of war in Iraq, misjudged the distinction between his legal and political roles. That body, in receipt of opinions by both Sir David and myself (provided in isolation from each other) rejected jurisdiction, leaving Lord Goldsmith to the no doubt tenderer mercies of the Chilcott Inquiry. ${ }^{83}$ It seems to me inevitable that the role of the Attorney-General will have to be de-constructed, like that of the Lord Chancellor, and for analogous, if not identical, reasons of disentangling roles seen to be in tension. Wearing two hats is less difficult than wearing three, but a single item of headgear is more becoming.

There are institutional as well as ideological pressures on the independence of the Bar. Sir Gavin Lightman in a much discussed lecture "The Civil Justice System and Legal Profession - the Challenges Ahead", ${ }^{4}$ somewhat like a former cabinet minister, freed from the burdens of collective responsibility, rediscovered the path of true principle for the profession he had left a decade before. He excoriated "the metamorphosis of the legal professions into legal business" 85 and the consequent impact on the internal organisation of the Bar.

"The dominant philosophy today amongst many chambers", he wrote "is to place the highest premium on keeping all available work for clients "in house". Indeed chambers have increasingly in all but name and law become partnerships between the members committed to the pursuant of the best interest of members. Chambers have for practical purposes a corporate existence. Chambers increasingly publish legal works as a chambers exercise to publicise the chambers and attract the work to the chambers. Chambers have put into effect "rules" (enforced by chief executives and barristers' clerks) that, when counsel has been instructed from amongst the members of the chambers, if that counsel requires a leader or junior, that leader or junior will be selected from the available pool in that chambers (mopping up local employment) rather than on the basis of talent or

\footnotetext{
${ }^{83}$ In the event, the Bar Council concluded that it had no jurisdiction in relation to his position as a Minister of the Crown, though enjoying it in relation to his performance of his role as Counsel in court or discreditable conduct in his personal life (a decision of 7 July 2005).

${ }^{84}$ (2003) 42 Civil Justice Quarterly 235.

85 243. See too in Arthur Hall, Lord Steyn at 682 “The world has changed since 1967. The practice of Law has become more commercialised.”
} 
price (the relevant considerations for the client) from the available pool of the Bar as a whole., ${ }^{, 6}$

There is, if not a ring, at least a tinkle of truth in what he says. For what is certain is that the perception of the Bar from outside has altered.

A decade ago, ${ }^{87}$ an issue arose whether a barrister who had been appointed an arbitrator by one party to the arbitration should be removed by the Court on the ground that another barrister from the same chambers had been instructed in the arbitration that gave rise to justifiable doubts about the arbitrator's impartiality.

Rix $\mathrm{J}$, in rejecting the application, ${ }^{88}$ emphasised the uniqueness of the Bar's organisation and the fact that it provided a structural protection both for the interests of the client and for the interests of justice:

"It is the essence of practice at the bar, as that barristers are all selfemployed. This is not a mere matter of form. On the contrary, practising barristers are prohibited by the rules of their profession from entering partnerships or accepting employment precisely in order to maintain the position where they can appear against or in front of one another. If it were otherwise, public access to the bar would be severely limited: each time a member of a set of chambers accepted instructions, he would debar any other member of those chambers, although independently practising self-employed barristers, from accepting instructions from any other party with a different interest in the dispute; nor would he be able to appear before a Recorder, Deputy Judge or arbitrator in the same proceedings. This would be a severe limitation on the administration of justice in this country." 89

Several years later an ICSID Tribunal, considering the converse situation that is, whether a QC could any longer act as counsel in a case where a member of the Tribunal was from the same set, decided that what Rix J had seen as a matter of substance was or would be seen as a matter of form. Accepting that de jure barristers in a set of chambers were independent of each other, the Tribunal ruled that they would be seen de facto as having a collective connotation. ${ }^{90}$

\footnotetext{
${ }^{86} 244$

${ }^{87}$ Laker Airways Inc v FLS Aerospace Ltd and Burnton [1999] 2 Lloyds's Reports 45. ${ }^{88}$ The test under the Arbitration Act 1996 was whether circumstances existed: section 24(1)(a).

${ }^{89}$ At p 52: See too Background Information on the IBA Guidelines on conflicts of interest in International Arbitration.

90 They held:
} 
This warning flags are fluttering elsewhere. The Court of Arbitration for Sport, whose adjectival law is substantially Swiss, regard, in the words of its Secretary-General, the notion of a member of a set of Chambers acting as arbitrator when a party is represented by a member of the same set as "problematic", ${ }^{11}$ although I have never in all my time at the Bar expected, still less received, favours from judges whom I know well.

The problem will be exacerbated if barristers exploit the permission newly given, to work in partnerships, or in both a self-employed and employed capacity at the same time (though not in the same case!), ${ }^{92}$ or to become managers in and hold shares in Legal Disciplinary Practices (LDPs), the more so if they participate in the Alternative Business Structures ("ABS") contemplated by the same legislation which would allow them to work alongside both other legal professionals and non-lawyers - a development optimistically described by Lord Falconer as the legal system's Tesco. The influence of outside ownership, the promotion of profit over professional standards, and the commodification of legal issues, all threats inherent in these putative entities may yet cause us to mourn the eclipse of - at one and the same time - to embroider the analogy - the neighbourhood cornershop and Harrods.

Similar concerns are generated by the serious commercial pressures on substantial sections of the Bar. Within what the Chairman of the Bar has recently called "an increasingly broad church",93 there are in fact many Bars.

"The objection in this case is not predicated on any actual lack of independence or impartiality, but on apprehensions of the appearance of impropriety. In the interest of the legitimacy of these proceedings, the arbitrators consider that the Claimant is entitled to make this objection and that it is well founded." but mitigated this by adding:

"The Tribunal does not believe there is a hard-and-fast rule to the effect that barristers from the same Chambers are always precluded from being involved as, respectfully, counsel and arbitrator in the same cases. Equally, however, there is no absolute rule to opposite effect. The justification of an apprehension of partiality depends on all relevant circumstances.”.

Indeed in 2010 a Tribunal acting within the same jurisdiction affirmed the power to exclude counsel, but declined to do so, and distinguished the earlier case http://ita.law.uvic.ca/documents/RompetrolParticipation.pdf - last accessed $2^{\text {nd }}$ June 2011.

${ }^{91}$ A letter sent by him to me when a party represented by a member of my Chambers sought to appoint me as arbitrator.

92 The Legal Services Board approved the Bar Standards Board applications designed to relax provisions in the Code of Conduct for barristers working practices. Counsel: May 2010, BSB News IV. The fons et origo of these developments was the Legal Services Act 2007.

${ }^{93}$ Chairman's Report January 2010. 
Those who depend upon public funds, in particular in the areas of criminal and family law, suffer, if not death, at least damage by a thousand cuts. Freeze has been followed by fall. Judicial review of the latest pre-election Government decision was briefly on the agenda. ${ }^{94}$

The outgoing Minister for Justice retorted by identifying, with less than complete accuracy, the top legal aid earners for 2008-2009 as if the income of the few was characteristic of the income of the many. The hourly earnings of the majority were, in a counter-attack, described by the Chairman of the Criminal Bar Association as less than those of a garage mechanic. ${ }^{95}$ This led predictably to an amusing, if unedifying correspondence in the letter column of the Times as to which provided a more valuable social service.

The real victims, of course, will be the most vulnerable members of society - who are not, I hasten to add, the barristers themselves - to whom the barristers, distracted by a wish, in no way dishonourable, to receive a reasonable income for demanding work will increasingly be inhibited in their ability to provide proper representation, and may be even compelled to avail themselves of the exit route permitted by the cab-rank rule itself.

The palliative of conditional fee agreements, shifting the burden of financing of many types of litigation from state to persons, natural or legal, ${ }^{96}$ and now available in all except criminal and specified family proceedings, confers on barristers, as Sir Gavin Lightman pointed out:

"a financial interest in the outcome of litigation in which they are engaged which is calculated to create unacceptable conflicts of interest and duty and creates unacceptable pressures to win."97

In this uncertain financial climate Baroness Deech, the Chairman of the BSB, has said:

"We have to negotiate a path between the Scylla of fusion and the Charybdis of attrition of the Bar."

In identifying the perils on that path I have sought tonight to make a summary case for the survival of a professional, independent in mind, spirit and appearance, and a member of a profession itself independent, [though not unaccountable]; capable when called upon, of defending individual rights against the power of an ever burgeoning state and its sundry satrapies, but

\footnotetext{
${ }^{94}$ Counsel May 2010 p 4.

${ }^{95}$ Letter The Times March $29^{\text {th }} 2010$.

${ }^{96}$ See Walker and Walker, Above n 9 pp 400-401, 525-527.

${ }^{97}$ Above n 86, at p 243.

${ }^{98}$ Speech to the Young Bar Association October 2nd 2009.
} 
equally of representing the state when it seeks to enforce the public interest against those who act in a way inimical to it. In a surface sense everything has changed. In a subterranean one nothing has - or should. The environment in which the Bar operates at any one time may be ephemeral: but its values must be eternal.

In his book The End of Lawyers? ${ }^{99}$ Richard Susskind, a proselytiser for information technology explains, albeit in a footnote.

"I reiterate the question mark in the title is intended to confirm that this book is an inquiry into whether lawyers have a future rather than a prediction of their demise". ${ }^{100}$

And, equally mercifully, while prophesying that:

"lawyers who are unwilling to change their working practices and extend their range of services, will, in the coming decade, struggle to survive", ${ }^{101}$

adds

"dispute avoidance and online dispute resolution will chip away at some of this domain, but I do not see these as eliminating advocacy entirely". ${ }^{102}$

So I end by considering the moral issue created by the art of advocacy itself. $^{103}$

A recent consultation paper by a trio of legal regulators described Advocacy as "a fundamental pillar of the Justice system", ${ }^{04}$ as certainly it is, viewed from a national perspective. Lord Hoffmann noted that:

${ }^{99}$ R Susskind The End of Lawyers?: Rethinking the Nature of Legal Services (OUP, 2008).

${ }^{100}$ Ibid p 269 n1.

101 Above n99, p 269.

102 Above n99, p 274.

${ }^{103}$ See Ridalgh v Horsefield [1994] Ch 205 at 236 "Advocacy is more an art than a science. It cannot be conducted according to formulae. Individuals differ in their style and approach”. Sir Thomas Bingham MR at p 236.

See “Advocacy as Art” Michael Beloff QC, The Margaret Howard Lecture, Oxford 2000. “Advocacy: A Craft Under Threat” Michael Beloff QC, “The First Hans Espeland Lecture” Oslo 2002.

104 Joint Consultation by the SRA Ilex Professional Standards and the BSB. “Advocacy Standards” 2009 para 2. 
"the substantial orality of the English system of trial and appellate procedure means that the judges rely heavily upon the advocates appearing before them for a fair presentation of the facts and adequate instruction in the law...

The Court procedures of Europe and the United States, for example, lack the predominantly oral character of litigation in the United Kingdom”. ${ }^{105}$

It is regarded as axiomatic that the services of a professional advocate are beneficial: whether of Cicero, the hero of Robert Harris' projected trilogy, of William Murray, later Lord Mansfield, of whom Alexander Pope hymned:

"Graced as thou art with all the power of words,

so known, so honoured in the House of Lords"

- a couplet which have required modification had the Supreme Court been established 300 years ago - and which was parodied by the actor Colley Cibber, a victim of Murray's eloquence, in a style worthy of William McGonagle:

"persuasion tips his tongue whene'er he talks.

And he has chambers in the Kings Bench Walks".

Of Clarence Darrow who in the Scopes trial, proved a more doughty destroyer of creationism than even Richard Dawkins, and was memorably played by Spencer Tracy in the film Inherit The Wind, or of modern giants such as Sir Sidney Kentridge or the late George Carman. There is much nice learning on whether and when natural justice requires that barristers' use be permitted or required. ${ }^{106}$

Indeed the principle of equality of arms, inherent in the right to a fair hearing guaranteed by Article 6 of the European Convention on Human Rights, requires that everyone who is a party to proceedings must have a

\footnotetext{
${ }^{105}$ Arthur Hall at 692 and 695.

${ }^{106}$ When Governors had refused a teacher accused of sexual misconduct with a pupil legal representation at a disciplinary hearing, Laws LJ observed that the outcome of the proceedings could irretrievably prejudice his ability to practice his profession and continued:"Within the proper confines of the evidence, a professional advocate might properly make a great deal of difference to the flavour and emphasis of the governors conclusions, and, if there were any contest as to the primary facts to that too".

The Governor of X School and The Queen on the Application of G and Y City Council [2010] EWCA Civ 1 at para 48.
} 
reasonable opportunity of presenting his case to the Court under condition which do not place him at a substantial disadvantage vis à vis his opponent. ${ }^{107}$

But equality of arms does not mandate parity of representation. It has been held that a fair trial does not necessarily entail representation by a QC merely because the Crown is represented by one. ${ }^{108}$

"The importance" said Lord Woolf "is to have an advocate, whether he be a barrister or solicitor, who can ensure that a defendant's defence is properly and adequately placed before the Court". ${ }^{109}$

Up to a point Lord Woolf... for there are but two possibilities. Either the relative quality of representation has no impact on the outcome or it does. The first possibility is at odds with everyday experience in the Courts. In another context Mr Justice Megarry wisely said:

"As everybody who has had anything to do with the law well knows, the path of the law is strewn with examples of open and shut cases which, somehow, were not”. ${ }^{110}$

Claims in civil cases should not reach the stage of requiring adjudication by judge or arbitrator unless there was at least some scope for more than one outcome. Prosecutions would, at any rate should, not be brought or pleas of not guilty entered unless there is a measure of uncertainty, however, small about the verdict. It is precisely to alter the odds that particular advocates are selected. A senior silk at the top of his game is worth as much to a legal, as a Rooney, a Ronaldo or a Messi is to a football team. Let me call two witnesses from north and south of the Equator.

First again, Sir Gavin Lightman who said:

“A party's performance at the trial very much turns on the investment made by the respective parties in the litigation: at all stages in the litigation money talks loud and clear. The human right to equality of arms has little, if any, meaning or practical effect in this context and

\footnotetext{
${ }^{107}$ In $A B$ Slovakia the ECtHR held that by proceeding in the applicant's absence and, by failing, prior to that, to take a formal decision on her request for the appointment of a lawyer, the Bratislava Regional Court deprived the applicant of the opportunity to present her case under conditions of equality vis a vis a defendant.

${ }^{108} R$ v Lea, Shatwell \& Attorney General's Reference No 82 of 2000 [2002] EWCA Crim 215.

${ }^{109}$ Lord Woolf at para 14.

110 John v Rees [1970] Ch 345 at 402.
} 
the judge, however fair-minded and interventionist, has limited scope to redress the balance. A litigant purchases the quality of justice he can afford. The quality of solicitors and counsel varies as does the quality of wine from "unfit to drink" to vintage. Vintage tends to be very expensive beyond the means of the ordinary litigant. Most must be satisfied with "plonk". A failure of advice at the first stage is calculated to cause irreversible harm. The prospects of success of a case very much turn on the quality or lack of quality of preparation for trial. Cases are won and lost by reason of the quality of representation at the trial: hence the extravagant fees paid to litigation lawyers. Tell it not in Gath but the scales of justice favour those who can afford to buy it." "111

Second, if more succinctly Michael Kirby the peripatetic former Antipodean High Court Judge who wrote:

"In an adversarial system such as exists in the UK and Australia, the party that argues most persuasively will often win the day."112

It is not always the case that he who pays wins: but it is certainly the case that whereas all barristers are equal, some are more equal than others. Geoffrey Robertson QC entitled his interim autobiography "The Justice Game". ${ }^{113}$ Contests between unevenly matched contestants may be acceptable in a game, but not when justice is the intended trophy.

It would be little consolation to the clients of Jerry Guerinot, twenty of whose clients have been sentenced to death in Texas, that Vanessa D. Gilmore, the Federal Judge in Houston, in turning down an appeal by a British woman, Linda Carty, convicted of murder which was grounded on Guerinot's incompetence in handling of her case said without conscious irony "The Constitution does not require perfection in trial representation."

There may be a hollow in the crown of the adversarial system but how it is to be filled, in the real, as distinct from the ideal world, I confess do not know.

But let me not conclude on so dispiriting a note!

In Metcalf v Mardell ${ }^{115}$ Lord Hobhouse said:

111 CJQ 238.

112 The Hon Michael Kirby “The common law and international law - a dynamic contemporary dialogue” (2010) 30 Legal Studies 55.

113 Above n 30.

${ }^{114}$ New York Times, May $18^{\text {th }} 2010$.

115 [2001] 1 AC 120. 
"The judicial system exists to administer justice and it is integral to such a system that it provides within a society a means by which rights, obligations and liabilities can be recognised and given effect to in accordance with the law and disputes, justifies (and efficiently) resolved. The role of the independent advocate is central to achieving this outcome". ${ }^{116}$

So in a lecture which is inevitably decked out in borrowed plumes, I hope I may be forgiven for plagiarising myself with a tail feather:

“They also serve who only stand and speak". 117

${ }^{117}$ M Beloff QC “Judicial Review 2000 - a Prophetic Odyssey” (1995) 58 MLR 143. 